\title{
Stone artefacts and recent research in the archaeology of mainland Southeast Asian hunter-gatherers
}

\author{
Ben Marwick \\ Department of Anthropology, Campus Box 353100, University of Washington \\ Seattle, WA 98195-3100 USA \\ bmarwick@u.washington.edu
}

Keywords

Stone artefacts, Thailand, Pleistocene, Holocene, behavioural ecology

\begin{abstract}
In recent decades the study of stone artefact technology has made many technical advances and substantial contributions to the archaeology of many regions. Until recently, mainland southeast Asian has benefited little from these advances, in part because of the paucity of evidence and in part because of prevailing conceptual frameworks that were poorly suited to the available evidence. The Middle Pleistocene record has a very sparse lithic record suggestive of little more than the presence of hominins on the landscape. The Late and Terminal Pleistocene is better represented and recent work on stone artefact assemblages has demonstrated that the assemblages document important behavioural variation that challenges previous notions of Pleistocene huntergatherers in mainland Southeast Asia. Holocene assemblages, especially from Luang Prabang and the Salween River areas, hold promise for addressing questions about the transition to agriculture, currently a poorly understood process in mainland Southeast Asia.
\end{abstract}

\section{Introduction}

Mainland Southeast Asia is well known amongst archaeologists and the public for its ancient monumental architecture and excavations of large cemeteries at metal-age sites, for example in Thailand and Vietnam. Less well known are the earlier periods represented only by two broad and unspectacular categories of material culture: stones and bones. In this paper I draw mostly on the stone artefact record of human forager groups in mainland Southeast Asia (figure 1) to examine the current state of particularly salient issues. I also attempt to synthesise some recently accumulated evidence and summarise some new perspectives on archaeological problems in mainland Southeast Asia. This region is defined as Thailand, Cambodia, Laos and Vietnam, especially the regions with seasonal tropical vegetation, but the focus will be on Thailand because of my familiarity with its archaeology and the availability of published research relative to the surrounding countries.

First, Middle and Early Pleistocene is still largely a blank for mainland Southeast Asia. Early reports of stone artefacts attributed to the Lower Palaeolithic can no longer be relied on. However recent work at the Lampang basalts suggests these are likely to contain important materials from this period. Evidence relevant to modern human colonisation and behav-

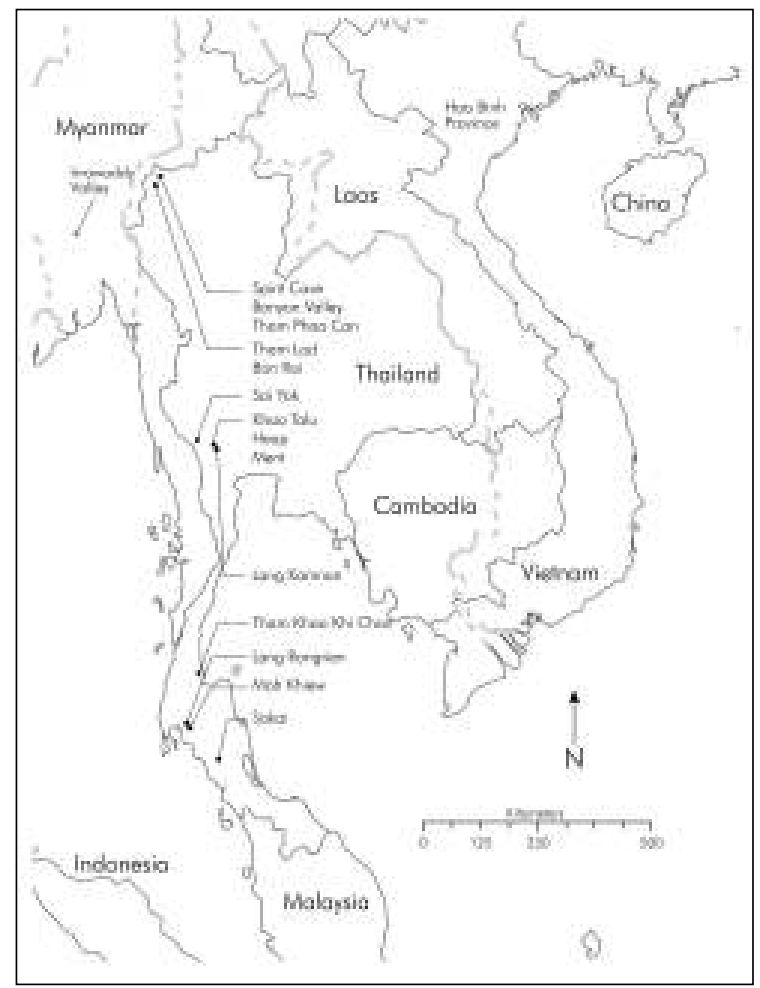

Figure 1 Map of sites and regions discussed in the text 
iour is currently obscure, but is likely to come from Tham Lod rockshelter and Lang Rongrien rockshelter if these sites are re-examined with modern dating techniques. Second, the range of behavioural variation for Late Pleistocene hunter-gatherers has recently been shown to be more subtle and variable than previously described. This is especially notable during the Pleistocene-Holocene transition. These new observations are a result of a shift away from traditional culture-historical frameworks towards behavioural ecological frameworks. Finally, some significant Late Holocene technological changes are described and two specific geographical areas are argued to have special potential in contributing towards a better understanding of these changes and their relationship to the emergence of agriculture.

\section{History and context}

The legacy of previous work is strong in mainland Southeast Asia, especially that of Colani (1927) and Movius (1948). Colani's work was a culture-historical approach that interpreted visually distinctive flaked artefact forms as diagnostic indicators of cultural groups. One prominent example is the Hoabinhian group. The endurance of this interpretation and its variants is probably due to its convenient simplicity and nationalistic interests in demonstrating cultural connections between the present and deep past (Miksic 1995; Glover 1993,1999, 2001). Another reason for its endurance is Colani's French background, with more recent French work in mainland Southeast Asia (eg, Forestier 2000) continuing the tradition of concentrating their analysis on visually distinctive artefact forms. Bowdler's (2006; Bowdler \& Tan 2003) work represents an updating of this culture-historical approach with claims that the distribution of sumatraliths, as the fossil directeur of the Hoabinhian, reflect the diffusion of specific gender-specific subsistence or ritual activities. (A sumatralith is an elongated cobble with a distinctive unifacial invasive flaking pattern, Shoocongdej 2001). The endurance of this focus on visually distinctive artefact forms - also known as types - is also related to the training that many archaeologists receive in Old World archaeology which is still based on typological sequences. This approach depends of a philosophy of classification that understands visually distinctive artefacts as essential unchanging types, which is problematic because of the continuous nature of stone artefact reduction (Marwick 2008a). Archaeologists adhering to this problematic philosophy of classification cannot escape it without abandonment of the typological research programme, which is likely to be a very gradual process.

Movius' influence can be seen in interpretations of flaked cobbles, especially larger cobbles (>1 kg) with relatively small numbers of flake scars, as evidence of extremely ancient human activity. These interpretations are often based on little else than the appearance of small numbers of these large artefacts. For example, Forestier et al (2008) conclude from the morphology of ten flaked stone artefacts found in surface contexts that the assemblage is Lower Palaeolithic in age. They describe one piece as a 'cortical trihedral pick' and argue that this piece indicates that an Acheulean variant may be present in Thailand. Moore and Brumm (2007) note that this attribution of 'core tool' assemblages to great antiquity is prevalent in island Southeast Asia also.

The consequence of these legacies is that they have maintained an epistemology of stone artefact analysis in mainland Southeast Asia that has little resemblance to the most productive current approaches to stone artefact analyses. This work is focused on emphasising the reductive process of knapping as a means of understanding technological variability in the archaeological record (Collins 2008). This approach is based on the understanding that flaked stone artefacts vary progressively from first use to discard by decreasing in size and changing in form depending on extent and pattern of the knapping that they experience (Shott \& Weedman 2007). Variations in the extent of knapping are often interpreted using generalised ecological theories that explores links between changes in the organisation and efficiency of technology and environmental conditions (McCall 2007; Mackay 2008; Kuhn 2004).

An important implication of this epistemology in mainland Southeast Asian stone artefact analyses is that behavioural and evolutionary issues that have recently been aggressively debated elsewhere have received relatively little attention in Southeast Asia. These issues include the role of technology in the first hominin colonisations of the region (cf Arribas \& Palmqvist 1999; Choi \& Driwantoro 2007), technological changes surrounding the local appearance of anatomically modern humans (cf Ambrose 2002; Foley \& Lahr 2003; Hiscock \& O'Conner 2006), the interpre- 
tation of regional variation in forager technology (eg, Attenbrow 2007) and technological changes surrounding the advent of domestication (cf Denham 2007; Abbott et al 1996). Some of these topics have been recently pursued in island Southeast Asia, particularly as a result of the discovery of Homo floresiensis (Moore \& Brumm 2007) but they are noticeably absent in the literature of mainland Southeast Asia. In the following sections I attempt to bring available evidence to bear on some of these issues in an attempt to reorient research priorities in mainland Southeast Asia towards more productive frameworks.

\section{Early and Middle Pleistocene}

One of the most obvious reasons why mainland Southeast Asia features so little in narratives of early hominin evolution is because of the paucity of remains that have been recovered from the region. This is mostly due to historical reasons, with mainland Southeast Asian palaeoanthropology and Pleistocene archaeology receiving relatively little academic and public interest locally and internationally. That said, there are numerous sites with extinct fauna in Thailand, Vietnam and Laos that are contemporary with Middle Pleistocene hominins known from elsewhere in Asia (ie, the Ailuropoda-Stegodon faunal complex [Fromaget 1940; Chaimanee \& Jaeger 1994; Tougard 2001; Bekken et al 2004; Demeter et al 2004]). Small amounts of hominin skeletal remains have been found with these faunal deposits in Thailand and Vietnam (Tobias 2002; Demeter et al 2004) but substantial amounts of hominin material culture are yet to be recovered. Although the hominin evidence is not numerous - especially from reliably dated contexts - it does suggest some evolutionary hypotheses to motivate continuing investigation. The following discussion is limited to specimens that have chronological control provided by absolute dating methods (with one exception - Had Pu Dai). This excludes a number of biostratigraphically dated hominin specimens (Ciochon \& Olsen 1986; Olsen \& Ciochon 1990). These finds typically derive from cave or river terrace deposits with complex depositional histories that are not described sufficiently to have confidence in the claimed biostratigraphic associations. Also, many of these undated remains are heavily worn teeth, making morphological comparisons unreliable, especially given the similarities between Homo erectus and
Homo sapiens and between Homo and Pongo (Olsen \& Ciochon 1990; Schwartz et al 1995).

\subsection{Mae Tha and Kao Pah Nam, Thailand}

The earliest evidence for hominins in mainland Southeast Asia is claimed by Pope (1985; Pope et al 1986, 1978) as three flaked stone artefacts recovered from surface fluvial gravel deposits at Mae Tha in Lampang Province, northwest Thailand. The age of the artefacts is argued to be about $0.8-0.6 \mathrm{Ma}$ because the fluvial gravels containing the artefacts are stratigraphically below a basalt layer that has been magnetically dated to $0.73 \mathrm{Ma}$ (Barr et al 1976) and radiometrically dated with $\mathrm{K}-\mathrm{Ar}$ isotopes to $0.8 \pm 0.3$ Ma and 0.6 \pm 0.2 Ma (Sasada et al 1987). Pope et al (1978) have also claimed that three flaked stone artefacts and one manuport recovered from excavations at Kao Pah Nam, also in Lampang, have a similar age. This is based on claimed similarities in morphology and lithology to the Ban Mae Tha artefacts, the location of the cave in relation to the dated basalt strata and extinct fauna such as Crocuta, Panthera and Hippopotamus recovered from the excavation. Direct dates are not yet available for either the strata or fossils from Kao Pah Nam.

Although these finds have received some acceptance (Higham 1996; Tougard et al 1998), it is suggested here that the physical relationship between the artefacts and the dated strata is too distant to have confidence in a reliable association between them. The stratigraphic relationship between the fluvial gravel and the basalt is known from two wells located 150 and $500 \mathrm{~m}$ south of the artefacts (Pope et al 1986). A recent attempt in June 2008 by the author and Pope to relocate the location where artefacts were recovered was not successful because of extensive construction and landscape alteration. The absence of smaller flakes in the previously recovered material suggests that the artefacts may have been sorted by water flow and result from secondary deposition. The morphologies and lithologies of these surface finds are not restricted to the middle Pleistocene since similar morphologies and lithologies are known from throughout the Late Pleistocene and Holocene (Shoocongdej 2000; Moser 2001). This means that it is difficult to accept $0.8-0.6 \mathrm{Ma}$ as a reliable date for these finds and other claimed Middle Pleistocene surface assemblages in northern Thailand and eastern Cambodia. On the other hand, the association of 
stone artefacts with extinct fauna at Kao Pah Nam is more suggestive of a reliable Middle Pleistocene hominin context. The level of description currently does not permit conclusions about stratigraphic associations and integrity at Kao Pah Nam, but it does suggest that further investigations are justified at this location (Pope et al 1986).

\subsection{Had Pu Dai, Thailand}

The next oldest claimed evidence from the intermediate zone is a little-known find of four hominin cranial fragments in a breccia matrix at the front of a cave at Had Pu Dai in Lampang Province, Northwest Thailand (Pramankij \& Subhavan 2001a). The remains are briefly described by Pramankij and Subhavan (2001b) as four pieces that can be conformably refit to resemble the right frontal region of a calvaria with a very thick tabula externa, a thick dipole and very thin tabula interna. The curvature of the vault of the calvaria and the concavity behind the supraorbital torus are suggested by Pramankij and Subhavan (2001b) to resemble Asian Homo erectus specimens from Java and China. Although detailed morphometric data are not yet available for these pieces, their importance has been signalled by Tobias (2002), who inspected the finds and did not dispute the interpretation of Pramankij and Subhavan (2001b, 2001a).

There are no absolute dates available from $\mathrm{Had}$ $\mathrm{Pu}$ Dai but an age of $500 \mathrm{ka}$ is claimed by Pramankij and Subhavan (2001b, 2001a) based on extinct fauna recovered from the breccias. Detailed descriptions of the fauna are not yet available, but Tobias (2002) refers to Ailuropoda, sabre-toothed cats or lions, hyenas, cervids and suids. Other hominoid specimens include a possible Gigantopithecus tooth and a possible Pongo tooth (Pramankij \& Subhavan 2001b, 2001a). Despite the possible high significance of these finds and the imprimatur of Tobias, the $\mathrm{Had} \mathrm{Pu}$ Dai finds must be interpreted with caution until more detailed descriptions and absolute dates are available.

\subsection{Tham Kuyen and Lang Trang, Vietnam}

Five teeth identified as representing Homo erectus have been recovered from fossil bearing sediments in Tham Kuyen Cave in Land Son Province, northern Vietnam (Ciochon et al 1996). The teeth are identified as Homo erectus because of the peripheral placement of the molar cusps and close morphological affinities and crown area similarities with equivalent teeth from Zhoukoudian. Tham Kuyen is one of the better-known fossil sites in mainland Southeast Asia and has been under investigation for over 30 years. The fauna associated with the hominin teeth includes 36 mammal taxa, mostly extinct taxa such as Ailuropoda, Stegodon and Pongo (Olsen \& Ciochon 1990). A general estimate of the age of the faunal assemblage is $475 \pm 125 \mathrm{ka}$, based on averages age estimates using ESR (on tooth enamel) and U-series (on speleothem samples) methods (Ciochon et al 1996).

A similar assemblage of Ailuropoda-Stegodon fauna and Homo teeth has also been described from the Lang Trang Caves in northern Vietnam (Ciochon \& Olsen 1991). The hominid specimens are two molars, one premolar, one canine and one incisor and are attributed to Homo erectus based on the chronology of the site rather than morphology, which is not described. Three breccia samples with embedded fossil teeth were dating using ESR methods from $146 \pm 2$ ka to $480 \pm 40 \mathrm{ka}$. Although no stone artefacts have been found with these teeth, they are noteworthy because they support the idea of hominins inhabiting the landscape in mainland Southeast Asia during the Middle Pleistocene.

\subsection{Ma U'Oi, Vietnam}

The Homo remains from Ma U'Oi, Hoa Binh Province in Northern Vietnam consist of one maxillary molar, one left lower first molar and a small fragment of skull vault. These were recovered from excavations of fossiliferous breccias within the cave (Demeter et al 2005). The associated in situ mammalian fauna includes Elephas maximus, Rhinoceros cf sondaicus and Rhinoceros of unicornis that are argued to belong to the Ailuropoda-Stegodon complex, although neither of these two taxa are present (Bacon et al 2004). The fauna gives poor chronological resolution because most of the species present range through the Middle and Late Pleistocene and many are still extant. Absolute dates come from two samples dated by U-series methods. A piece of fossiliferous breccia gives an age of $193 \pm 17 \mathrm{ka}$ and a speleothem covering the fossiliferous breccia gives an age of $49 \pm 4 \mathrm{ka}$ (Bacon et al 2006).

These absolute dates add little resolution to the biostratigraphic chronology and the attributes and affiliation of the Homo remains are similarly ambiguous. The left lower first molar is heavily worn but dis- 
plays a mosaic of archaic and modern traits. Its dimensions fall within the range of Homo erectus from China, Indonesia and Vietnam and the crown is larger than Southeast Asian Homo sapiens (Demeter et al 2004). However, the molar crown is square like Homo sapiens and taurodontism - an archaic feature of Neanderthals and Homo erectus - is not present. The maxillary molar is more clearly Homo sapiens because of the crown dimensions falling within the range of Southeast Asian Homo sapiens and the absence of occlusal wrinkles, peripheral placement of cusps, apices and taurodontism (Demeter et al 2005). The skull piece is a mid-occipital bone fragment but insufficient features are present to permit taxonomic identification.

\subsection{Thum Wiman Nakin, Thailand}

A single Homo tooth was recovered from excavations of red clay sediments in the main chamber of Thum Wiman Nakin in Chaiyaphum Province, northern Thailand (Tougard et al 1998). The associated faunal assemblage suggests a Late Middle Pleistocene chronology and includes numerous extinct taxa including Pongo pymaeus, Ailuropoda melanolueca baconi, Crocuta crocuta ultima and Ursus thibetanus. As at Ma U'Oi, absolute dates have improved little on the biostratigraphic chronology. A large number of samples of travertine and teeth were dated using U-series methods, returning dates ranging from $8 \mathrm{ka}$ to 350 ka (Esposito et al 2002, 1998). Based on these dates the context where the Homo tooth was recovered was estimated to date to $169 \pm 11 \mathrm{ka}$. Esposito et al (2002) note that the wide range of results in the Useries dates, especially from the teeth, are significant because they demonstrate the complexity of $U$ series dating in tropical humid climates that result in highly variable rates of uranium uptake and leakage.

The Homo tooth from Thum Wiman Nakin is heavily worn and exhibits a mix of attributes from Homo erectus and Homo sapiens. The asymmetric crown shape and direction of the crown largest dimension resemble Homo erectus, but the completely fused root branches and occurrence of only one apex are specific to Homo sapiens (Tougard et al 1998). This mosaic of features resembles the left lower first molar from Ma U'Oi, but the heavily worn condition of both specimens prevents anything more than tentative attributions to archaic Homo sp for both.

These teeth from Ma U'Oi and Thum Wiman Nakin add little to our understanding of Middle Pleistocene hominin behaviour except to suggest that someone was on the landscape. While cave breccias are convenient places to find ancient teeth and bone, there are typically few relevant contextual data about hominin behaviour such as stone artefacts and hearths. Although the reliability of the Lampang sites is currently uncertain, they represent the possibility that open landscape features with Pleistocene stratigraphy could be a source of hominin cultural material from this period.

With the evidence currently available it is difficult to make persuasive statements about role of technology in the first hominin colonisations of the region. We do not yet seem to have any reliable evidence of what the earliest occupants of mainland Southeast Asia were doing although they were probably on the landscape by about $0.84 \mathrm{Ma}$, assuming that the hominins at this time traversed mainland Southeast Asia en route to Indonesia (Morwood et al 1998). If the artefact-bearing sites in Lampang be reliably dated to the Middle Pleistocene then the morphology and lithology of this technology is continuous into the Late Pleistocene and Holocene. This continuity of technology suggests that Moore and Brumm's (2007) claim for island Southeast Asia that early hominins and Homo sapiens practiced a broadly similar approach to stone flaking may also be applicable for mainland Southeast Asia.

\section{Late and Terminal Pleistocene}

It is not until much later in the Pleistocene at around $40,000 \mathrm{BP}$ that more robust evidence of stone artefact technology appears in mainland Southeast Asia. Under the direction of Rasmi Shoocongdej (2006; Shoocongdej \& Staff 2003), recent excavations at Tham Lod in north-west Thailand have provided important new evidence for human behaviour during the Late Pleistocene. Here I present some recently obtained dates that help define the antiquity of the sequence of occupation at Tham Lod. Of the three areas excavated by Shoocongdej, area one reached the deepest levels and had the least ambiguous stratigraphy (figure 2). The upper units of area one were disturbed by human burials (not visible in the section drawing) but from excavations unit seven to 32 the matrix is a consistent lightly-cemented combination of limestone cobbles and rocks, caliche and fine, well-sorted red-brown sediment. Large quanti- 


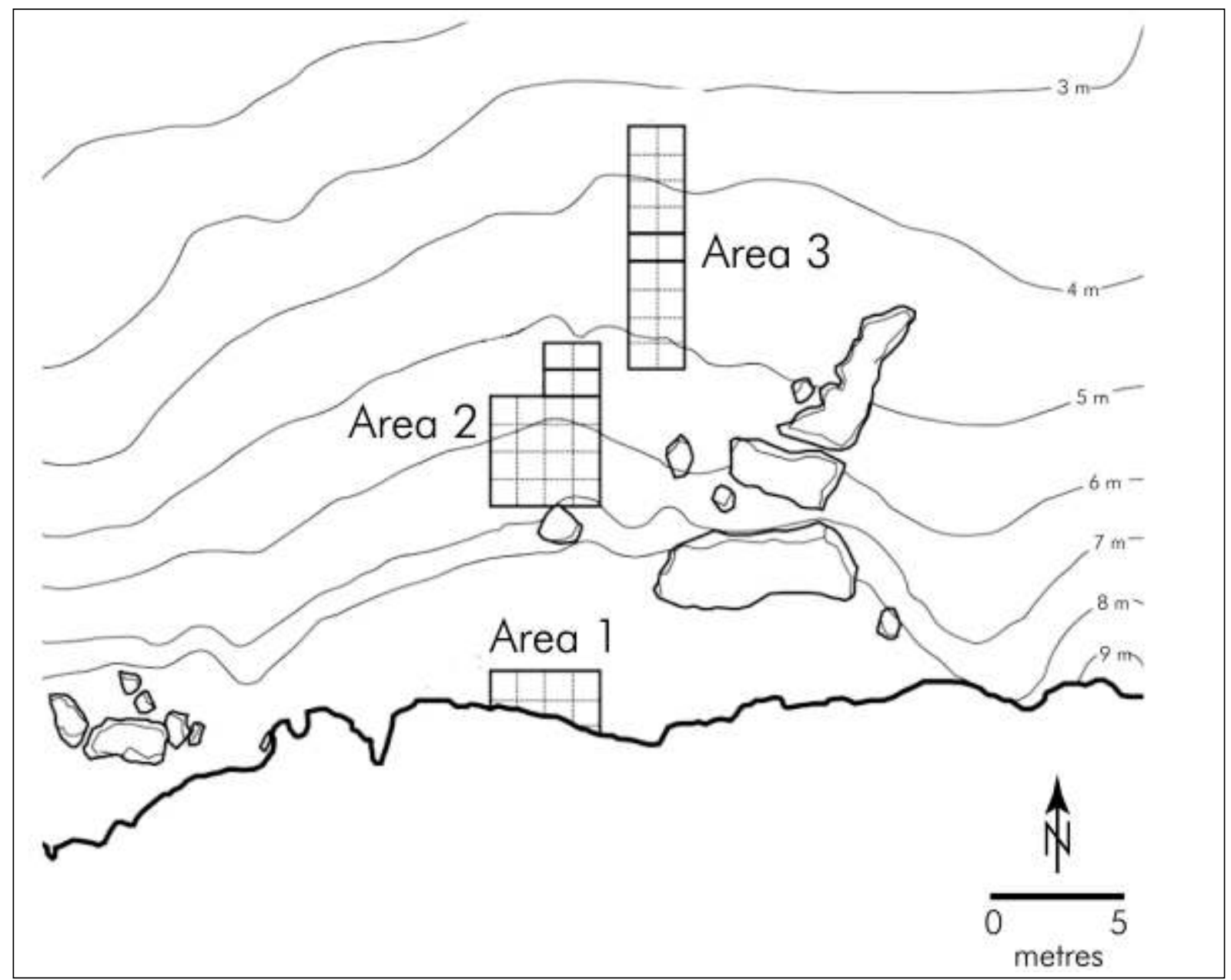

Figure 2 Plan of excavations at Tham Lod, Modified from Shoocongdej and Staff 2003

ties of river cobbles appear below unit 32 - partially visible in the section drawing as a concentration of larger rocks towards the north side - and then disappear again by unit 42 . This massively structured river cobble strata is interpreted by Khaokiew (2004) as an ancient river bed. No artefacts were found in or below this cobble layer.

Figure 4 shows a good correlation between depth and age from radiometric determinations obtained from Tham Lod area one. Dating the site was challenging because of the poor organic preservation in most units. This is a result of the rainfall that runs over the top of the limestone rockshelter, making the water weakly acidic, and then seeping through sediment matrix, dissolving organic materials. An example of the difficulties is illustrated by two samples of $500 \mathrm{~g}$ each of animal bone that were sent to the Waikato Radiocarbon Laboratory for dating only to find that the amount of datable carbon was below the level of instrument error. The oldest date from the site calibrates to 39,960 cal BP (table 1) using the
CALPAL2001 calibration curve in the CALPAL_A software (Weninger et al 2007) and is associated with the earliest artefacts deposited at the site. The total artefact assemblage at area one can be characterised as mostly unretouched quartzite and sandstone flakes and flaked pieces $(n=1827,94 \%$ of the total assemblage). In total 394 cores were recovered, mostly amorphous with five or fewer flake scars.

The first occupation of Tham Lod at around 39,960 cal BP is probably related to a change in the local hydrology, with the stream moving away from the rockshelter and creating a dry area suitable for habitation. Figure 5 shows the distribution of stone artefacts over time at Tham Lod, beginning with excavation unit 31, the lowest unit containing a minimum of ten artefacts at 34,900 BP. Small numbers of artefacts were recovered between units 31 and 40 and the low artefact density limits the confidence that can be placed in the analysis of the artefacts in these lowest units. The minimum numbers method of artefact quantification is described in Hiscock (2002). Fig- 


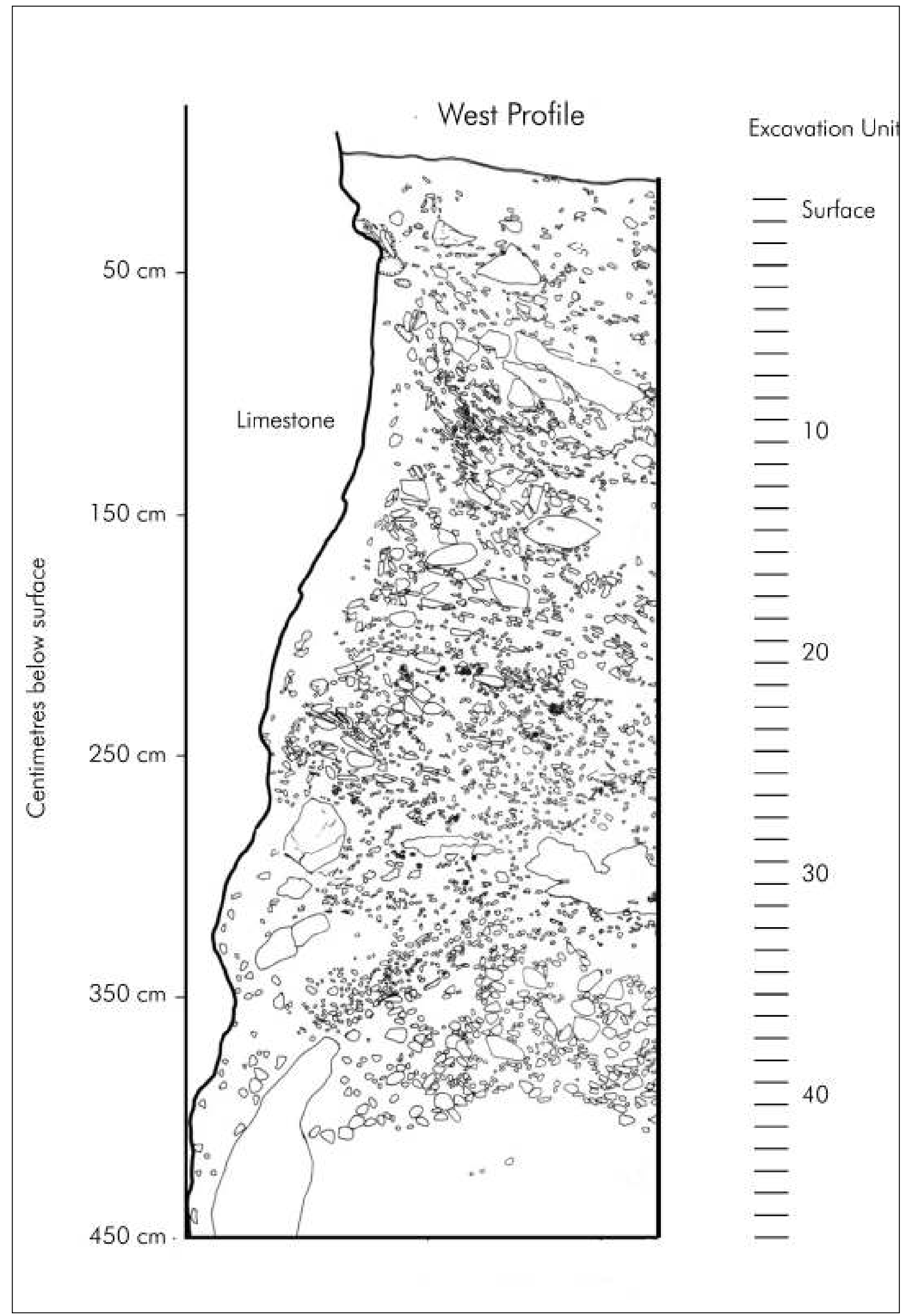

Figure 3 Stratigraphic section of Tham Lod area one. Modified from Shoocongdej and Staff 2003 
Table 1 Dates from Tham Lod area one. Dates without a standard deviation (SD) for the calibrated age were determined by thermoluminescence (TL) methods, the remainder were determined by AMS radiocarbon methods. All ages are in years BP. The absence of definite features in the deposit below the burials meant that the location of TL samples was arbitrary. Pre-treatment procedures between Beta and Wk dates are comparable but unknown for the Akita dates

\begin{tabular}{|c|c|c|c|c|c|c|}
\hline $\begin{array}{c}\text { Excavation } \\
\text { unit }\end{array}$ & Age & $\begin{array}{c}1 \text { SD } \\
\text { for age }\end{array}$ & $\begin{array}{c}\text { Calibrated } \\
\text { age }\end{array}$ & $\begin{array}{c}1 \text { SD for } \\
\text { calibrated } \\
\text { age }\end{array}$ & $\begin{array}{l}\text { Dated } \\
\text { material }\end{array}$ & Lab code \\
\hline $\begin{array}{l}4 \\
7 \\
9 \\
17 \\
18 \\
24 \\
27 \\
28 \\
31 \\
32\end{array}$ & $\begin{array}{l}12,100 \\
13,640 \\
13,422 \\
24,920 \\
20,000 \\
22,257 \\
29,318 \\
22,190 \\
32,380 \\
34,029\end{array}$ & $\begin{array}{l}60 \\
80 \\
541 \\
200 \\
117 \\
154 \\
336 \\
160 \\
292 \\
598\end{array}$ & $\begin{array}{l}14,070 \\
14,764 \\
13,422 \\
29,910 \\
23,900 \\
22,257 \\
34,500 \\
26,740 \\
32,380 \\
39,960\end{array}$ & $\begin{array}{r}140 \\
60 \\
270 \\
180 \\
500 \\
400 \\
1050\end{array}$ & $\begin{array}{l}\text { organic sediment } \\
\text { organic sediment } \\
\text { calcrete } \\
\text { charred material } \\
\text { Margaritanopsis laosensis } \\
\text { sedimentary quartz } \\
\text { Margaritanopsis laosensis } \\
\text { shell (unspecified) } \\
\text { organic sediment } \\
\text { Margaritanopsis laosensis }\end{array}$ & $\begin{array}{l}\text { Beta-168223 } \\
\text { Beta-168224 } \\
\text { Akita-TL7 } \\
\text { Beta } 194122 \\
\text { Wk-20398 } \\
\text { Akita-TL12 } \\
\text { Wk-20399 } \\
\text { Beta-172226 } \\
\text { Akita-TL10 } \\
\text { Wk-20400 }\end{array}$ \\
\hline
\end{tabular}

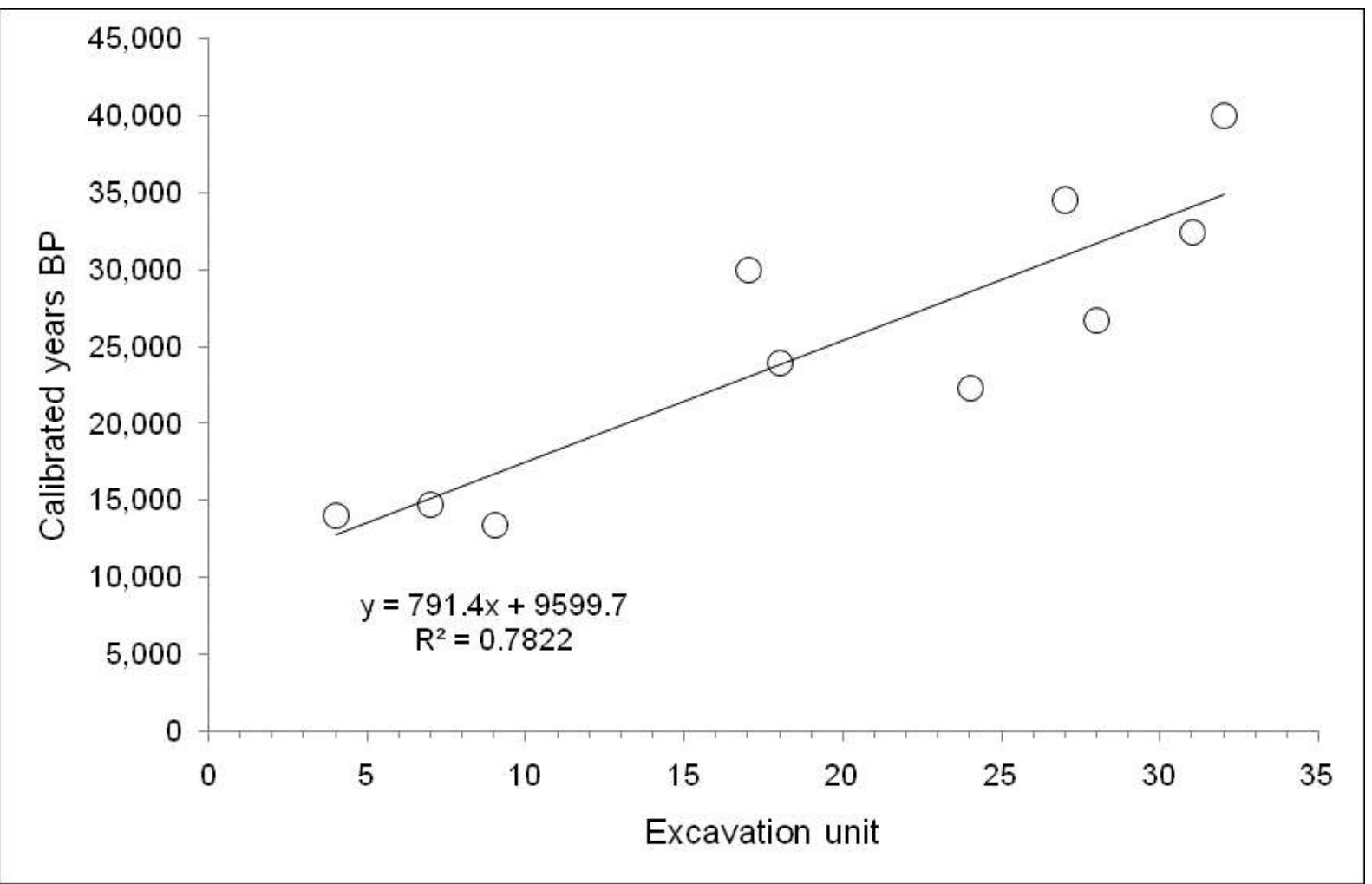

Figure 4 Age-depth plot for Tham Lod area one with linear regression line and equation

ure 5 shows that the period of most intense activity related to stone artefact discard was between 30,000 and 33,000 BP. If Tham Lod had a substantial depth of sterile deposit below the lowest artefacts then it might suggest that people were not in the area at all until about 35,000 BP. However, the geoarchaeology of Tham Lod, with the probable ancient streambed in the lowest levels, suggests only that this particular site was unsuitable for habitation during earlier periods because of stream-flow and does by itself not rule out earlier human occupation of the region.

Currently, Tham Lod represents the one of the oldest site of its kind known from mainland Southeast
Asia. It is a deep stratified rockshelter sequence with stone artefacts and faunal remains and as such is probably the most robust evidence of the first modern humans on the landscape. Similar in age is the site of Lang Rongrien in southwest Thailand, which has a date of $37,265 \pm 1000$ (PITT-1249, calibrates to 40,071 cal BP) associated with the lowest artefacts in an undisturbed strata (Anderson 1997). An older date of $43,000 \mathrm{BP}$ has been claimed for Lang Rongrien, but this date is ambiguous because it is described in published accounts as ">43,000" BP with no error range, so it is not clear if the age determination is actually $43,000 \mathrm{BP}$, much younger or even much older 


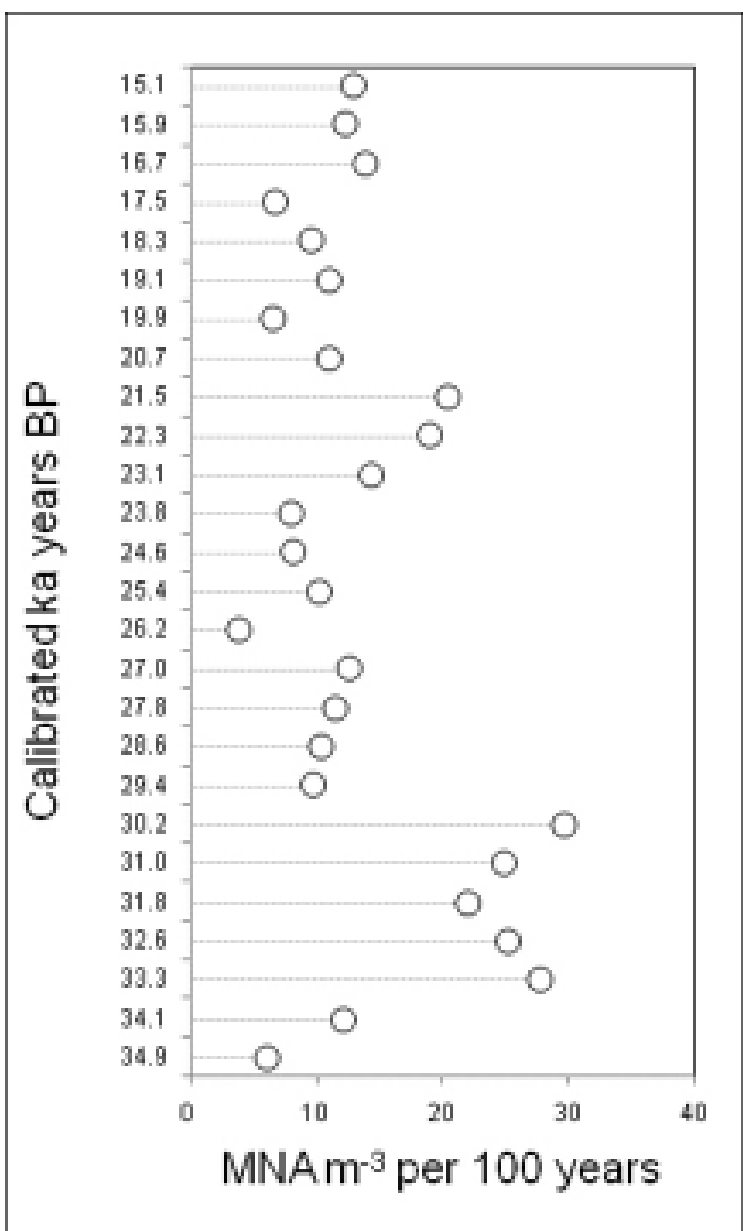

Figure 5 Vertical distribution of all flaked stone artefacts at Tham Lod area one. The horizontal axis shows the minimum number of artefacts per cubic metre per hundred years as a standardised artefact count

and beyond the reliable range of the method employed (Anderson 1997,1990).

In island Southeast Asia a slightly earlier timing for modern humans is evident at Niah Cave, Borneo. Stone artefacts are associated with charcoal dated to 46,000 cal BP (Barker et al 2007). A similarly early age is suggested at other island Southeast Asian sites. Uranium series dates on human bones at Tabun Cave (southern Philippines), range from 24,000 to 58,000 cal BP (Detroit et al 2004). These dates are less reliable than the chronology of Niah Cave because the Tabun Cave bones were recovered from disturbed stratigraphic contexts and their association with artefacts is uncertain. Further afield, marine shells in stratigraphic association with stone artefacts at Jerimalai (East Timor) have been dated to 42,000 cal BP (O'Connor, 2007). O'Connor observes that the stone artefacts recovered from Jerimalai are small flakes and cores with small numbers of retouched flakes and no typologically distinctive pieces. This technology is continuous from the Pleistocene to the later
Holocene and O'Connor notes similarities between the assemblages from Jerimalai and artefacts made by Homo floresiensis at Liang Bua. Moore et al (in press) similarly report that Liang Bua has 'straightforward' and 'uncomplicated' lithic reduction sequences and long continuity of technology over 95,000 years with only minor changes correlated with the appearance of Homo sapiens in the Holocene. These long-term similarities and persistence of relatively simple technologies in island Southeast Asia casts doubt on Foley's (1987; Foley \& Lahr 1997) claims of a relationship between specific hominid species and specific stone artefact technologies. It is also relevant that most recent Liang Bua artefacts, which were made during the terminal Pleistocene and Holocene, are very similar to the assemblage recovered from Early Pleistocene deposits at Mata Menge (Brumm et al 2006).

Even as far east as the Bismarck Archipelago near Papua New Guinea there are dates from shell recovered from stratified contexts that include human food refuse and stone artefacts that indicate human activity at 39,590 years ago (Leavesley \& Chappell 2004). This geographically wide spread of a relatively narrow range of dates for the first signs of modern humans suggests that the human colonisation of Pleistocene Sahul was a relatively rapid event (Leavesley \& Chappell 2004). These island sites indicate an emerging consensus of around 40-45,000 BP for the appearance of modern humans in Southeast Asia. Despite this apparent consensus, these dates are incongruous when compared to dates claimed for the appearance of modern humans in Australia. This event is claimed to have occurred between 50,000 and 60,000 BP (Roberts et al 1990, 1994; Thorne et al 1999; O'Connor \& Chappell 2003). However, these dates have been criticised as unreliable because of post-depositional movement of artefacts which weakens the association between the dated samples and the archaeological material. Hiscock (2008:37) and O'Connell and Allen (1998, 2004) show that artefacts have moved up to $8 \mathrm{~cm}$ through sediments at the Australian sites dated to 50-60,000 BP, resulting in a false association between artefacts and dated sediments. More reliable estimates come from a pit feature at Malakunanja II dated to 45-52,000 BP (Roberts et al 1990) and stone artefacts found with a human burial at Lake Mungo in sediments dated to 45-50,000 BP (Bowler et al 2003). 
This suggests that when similarly sophisticated approaches to age estimation and site formation processes are applied to mainland Southeast Asian sites a minimum age for first appearance of modern humans is likely to fall in the range of $45-50,000$ BP. With the current evidence from mainland Southeast Asia, it seems that the oldest sites for modern humans in Southeast Asia are not be representative of colonising populations of modern humans. However, new approaches to dating these sites that are equivalent to the dating techniques used in Australia may push back their chronologies to bring them in line with the chronology of Australian colonisation and make them relevant to the wider colonisation of Southeast Asia by modern humans.

\section{Terminal Pleistocene and Holocene}

It is not until much later that a richer record of huntergatherer hominin populations is available for mainland Southeast Asia. The earliest well preserved human skeleton appears at about 25,800 BP in association with flaked stone artefacts at Moh Khiew cave on the Malay Peninsula. Matsumura and Pookajorn (2005) compare the morphometry of the Thai skeleton to archaeological skeletons from Vietnam, Indonesia and Australia. They find that the Moh Khiew skeleton most closely resembles ancient Australian hominins from Coobool Creek because of its large alveolus, wide mandibular body and ramus, and buccolingually large maxillary teeth. They conclude that this individual represents a population of Sundaland dwellers during the Late Pleistocene who share common ancestry with the present-day Australian Aborigines and Melanesians (Matsumura \& Pookajorn, 2005). This possibility of a Pleistocene cultural connection between Australia and mainland Southeast Asia has also been pursued by Bowdler (1994, 2006; Bowdler \& Tan 2003) who has made some preliminary comparisons between Pleistocene stone artefacts from Australia and mainland Southeast Asia. She identified similarities in the proportions of metric and technological attributes (such as flake termination types) in assemblages from the two regions. Bowdler claims that they may signify a diffusion of technology or activities requiring a certain kind of technology across Southeast Asia and Australian during the Pleistocene. Phylogenetic analysis of samples of DNA taken from a molar root of this Moh Khiew skeleton shows a closer relationship to Papua New
Guinean populations than historical island or mainland Southeast Asian groups (Oota et al 2001). These morphometric and genetic data indicate that the Pleistocene populations of mainland Southeast Asia may have contributed little to current populations but instead may be remnants of a population that colonised as far as Papua New Guinea and Australia.

Marwick's (2007) review of previous work on the stone artefact technology of these Late and Terminal Pleistocene populations in Thailand critiqued a consensus view of cultural history that starts with flakebased assemblages from Lang Rongrien and Moh Khiew and then sees the introduction of Hoabinhian flaked cobble artefacts at around the PleistoceneHolocene boundary. The Hoabinhian is an ill-defined term that is generally applied to archaeological sites containing a sumatralith, which is an elongated cobble with a distinctive unifacial invasive flaking pattern (Shoocongdej 2001). An equivalent cultural history is also used in Vietnam where the early flake-dominated technologies have been labelled Ngoumian (Van Tan 1997). This is at odds with data from Tham Lod and Land Kamnan that show no evidence for a sustained high ratio of flakes to cores during the Pleistocene compared to the Holocene (Marwick 2008c; Shoocongdej 1996). They key implication here is that past characterisations of foragers as Pleistocene hunters and Holocene tree choppers is an overly simple caricature.

As well as being one of the earliest sites in mainland Southeast Asia, Tham Lod also offers a more detailed insight into the differences between Terminal Pleistocene and Early Holocene foragers. A second excavated rockshelter, Ban Rai is within $10 \mathrm{~km}$ Tham Lod although Tham Lod is near a river at $640 \mathrm{~m}$ above mean sea level (amsl) while Ban Rai is perched about 100 vertical metres up the side of a valley at about $760 \mathrm{~m}$ amsl. Both sites are in semi-evergreen forests but Ban Rai is close to an ecotone where a mix of dry dipterocarp and montane forests occur. This ecotone is important because it means prehistoric occupants of Ban Rai were well situated to access montane environments, which are likely to have been a focus of occupation given the distance to the river and difficulty of access.

The key detail from the histories of occupation of these two sites is that Tham Lod is almost exclusively a Pleistocene site (with the exception of a few recent surface finds) and Ban Rai is exclusively a 
Holocene site (although it was not excavated to bedrock, sterile sediments underlie the Holocene deposits). One possible explanation for this settlement shift is that the relatively cool and dry conditions of the Pleistocene (Maxwell \& Liu 2002) increased the importance of water as a scarce resource and as a result people concentrated their activities near sources of water. Following increased warmth and wetness during the onset of the Holocene, a location such as Tham Lod may have become less suitable for habitation because of increased density of vegetation, mosquitoes, and dampness. Instead, during the Holocene people appear to have preferred locations further from the river and more elevated, perhaps to provide better access to montane habitats that are easier to travel through for foraging.

Differences in the stone artefact technology between Ban Rai and Tham Lod are subtle, but suggest important shifts in the organisation of stone artefact technology from the Pleistocene to the Holocene that go beyond the simple flake-chopper progression described in earlier literature. Both assemblages are dominated by unretouched flakes and analysis of key indicators of assemblage reduction (Marwick, 2008d, 2008b) show that the assemblage at Ban Rai was more extensively reduced than the Tham Lod assemblage. These data, presented in detail in Marwick (2008c), suggest that foragers occupying Ban Rai tended to organise their technology around logistical strategies (with settlements from which small groups of people venture out to collect resources at distant or constantly shifting patches) more than the occupants of Tham Lod who employed more residential strategies (establishing residential camps at locations of relatively abundant resources to minimise longer distance forays). This shift in technology was probably not a direct response to climate change, but an outcome of the shift in the focus of settlement out of the low river valley and up closer to the montane habitats.

Culture-historical glosses used in other descriptions of mainland Southeast Asian stone artefact assemblages make it difficult to determine if the differences between Tham Lod and Ban Rai are part of a previously documented regional pattern or a unique expression. These glosses tend to homogenise sites by applying shared cultural and typological labels and suppress subtle differences related to human behaviour and adaptation. A related problem is the focus in previous work on a small number of visually distinctive flaked stone artefacts and little effort directed at the more numerous unretouched flake component. For example, in Bulbeck's (2003) comparison of four flaked stone artefact assemblages from the Last Glacial Maximum on the Malay Peninsula he found that Moh Khiew stands out with 60-64\% 'flake tools' in the Pleistocene layers compared to $0-20 \%$ at other sites. Bulbeck suggested that the discrepancy at Moh Khiew might result from differences in the classification system used by Pookajorn (1992) at Moh Khiew compared to the other sites. The problem of incommensurate recording systems between sites are not unique to mainland Southeast Asia, but the relatively small number of described sites in this region, the relatively amorphous assemblages and the lack of explicit definition of terms used in assemblage description makes the problem especially constraining.

\section{Middle Holocene}

Fortunately an example of two sites analysed by the same person using the same approach is available. Using these two sites I present here a brief explanatory sketch demonstrating an approach that contrasts with the culture-historical work that has dominated the region. This sketch is based on analysing strategies of technological organisation evident in stone artefact assemblages and testing hypotheses derived from models of human-environment interaction.

Reynolds (1989, 1992) has provided basic descriptions of stone artefact assemblages from Banyan Valley Cave in Mae Hong Son province in northwest Thailand and Tham Khao Khi Chan in Surat Thani province in southern Thailand. Radiocarbon dates from these sites indicate that Banyan Valley Cave was occupied around 900-5,300 BP and Tham Khao Khi Chan was occupied around 4,700-6,100 BP. Although very few details are available about the lithic landscapes surrounding these two sites, they provide a valuable opportunity for a preliminary investigation of

Table 2 Flaked stone artefact data from Banyan Valley Cave and Tham Khao Khi Chan. Summarised from Reynolds 1989,1992

\begin{tabular}{|l|l|l|}
\hline & Banyan Valley Cave & Tham Khao Khi Chan \\
\hline Unretouched flakes & $57.4 \%(n=927)$ & $\begin{array}{l}36.7 \%(n=123) \\
\text { Retouched and utilised flakes }\end{array}$ \\
$\begin{array}{l}0.9 \%(n=16) \\
\text { Cores and core tools }\end{array}$ & $0.7 \%(n=35)$ & $13.2 \%(n=51)$ \\
\hline
\end{tabular}


technological differences in the Middle Holocene between northern and southern Thailand. The two assemblages differ most fundamentally in the proportions of unretouched flakes which are the most abundant artefact types at both assemblages (table 2). The relatively low proportion of unretouched flakes at Tham Khao Khi Chan is complemented by much higher proportions of retouched and utilised flakes. Reynolds does not explain the difference between retouched and utilised flakes (presumably both types of flakes show some kind of edge modification, but how the two types are distinguished is not explained), so they are grouped together here. Tham Khao Khi Chan also has a higher proportion of cores and core tools than Banyan Valley Cave (table 2). The recognition here of differences in the two assemblages using these quotidian artefact classes - unretouched flaked, retouched flakes and cores - is an important methodological contrast to much previous work in the region. Previously, assemblage differences were only measured using small numbers of cores with visually distinctive forms, with the simpler and unpatterned artefacts largely ignored (eg, van Heekeren \& Knuth 1967; Pookajorn 1984).

A few simple statistics help to summarise the assemblage differences between the two sites. A chisquare test indicates that the differences in the quantities of these three classes of flaked stone artefacts between Reynolds' two sites is unlikely to be due to chance $\left(\chi^{2}=106.7\right.$, d.f. $\left.=2, p<0.001\right)$. If these differences are indicative of differences in technological organisation, then Tham Khao Khi Chan could be interpreted as an assemblage dominated by individual provisioning. Individual provisioning describes a strategy of keeping individual foragers supplied with the artefacts and raw materials they need as they move through the landscape (Kuhn 1995, 2004). At this site individuals appear to have provisioned themselves with artefacts that have undergone some processing and are ready for use, rather than less- or un-processed raw material nodules, which would involve carrying mass that is not immediately contributing to the usefulness of the artefact. On the other hand, Banyan Valley Cave represents an alternative strategy of technological organisation known as place provisioning. This refers to strategies that involve supplying artefacts and raw materials to places where activities are likely to be carried out. Banyan Valley Cave is typical of a place provisioning site because these locations will tend to be provisioned with raw material in various states of manufacture including unworked nodules ('broken pebbles' and 'natural stones' in Reynolds' system) and less-reduced specimens (Parry \& Kelly 1987). The ratio of flaked arte- $f$ facts to local natural stones at Banyan Valley Cave is 1:0.98 compared to 1:0.43 at Tham Khao Khi Chan, suggesting that unworked pieces may have been stockpiled to a greater degree at Banyan Valley Cave, typical of a place provisioning strategy.

Given these differences, the question is: are the different technological strategies a result of differences in latitude or differences in the local habitats at each site? Two sites are insufficient to make a convincing argument for either interpretation, and the level of description of the local habitats in the published accounts of each site is insufficient for conclusive comparison. The main point here is to highlight the need for descriptions of assemblages that are suitable for comparison and to propose hypotheses such as about technological economics - for testing as more data accumulate. An explanation based on latitude differences could be derived from Torrence's (1989) work on technology and time stress. Torrence argued for a relationship between technology and reliance on mobile food resources, using latitude as a proxy for the proportions of plants and animals available for consumption, which fewer plants available further from the equator because of shorter growing seasons. Torrence found a positive and significant correlation between toolkit complexity, toolkit diversity and latitude, offering strong support for her model. In the case of these two Thai sites, the difference in technology is the opposite to what Torrence's model predicts with the site closer to the equator, Tham Khao Khi Chan, having the more diverse and complex assemblage. That said, the scale of technological variation between the two Thai sites is very limited compared to the sample Torrence derived her model from which included snares and other kinds of unattended animal traps that have not been documented in the prehistoric archaeology of mainland Southeast Asia. The most parsimonious conclusion is that the differences between these two sites are a result of differences in the local environment and land use systems, but without information about the local environments of the sites, this conclusion is tentative.

Although the comparison between Tham Khao Khi Chan and Banyan Valley Cave is limited, these two 
sites represent the period of hunter-gatherer history for which the most evidence is available. Figure 6 shows the distribution of radiocarbon dates from a relatively large number of sites dominated by flaked stone artefact assemblages. Counts of radiocarbon dates can be used as a crude proxy for human occupation if the number of dates is proportional to the amount of datable material accumulated in sites due to human activity (Rick 1987; David \& Lourandos 1999) and time-averaging processes in deposit formation are equivalent across sites (Frankel 1988). Unfortunately few data are currently available to defend these assumptions at hunter-gatherer sites in mainland Southeast Asia, so careful attention to sedimentation rates and site formation processes should be priorities in future work to ensure comparability across difference sites. In figure 6 there is a clear peak between 11,000 BP and 4,000 BP, suggesting that either climatic conditions were unusually favourable for organic matter preservation during this time (cf Surovell \& Brantingham 2007), or that hunter-gatherer populations underwent a period of expansion. Occupation at the recently excavated Ban Rai rockshelter in northwest Thailand (Treerayapiwat 2005 ) is included in this expansion period with artefact-bearing strata dated between $6200 \mathrm{BP}$ and 9700 BP. The assemblage at Ban Rai is notable because the minimum number of flaked stone artefacts is an order of magnitude greater than at Tham Lod, the nearby Pleistocene site, suggestive of higher population densities during the Middle Holocene compared to the Late Pleistocene. Explanations for this early Holocene pattern in figure 6 are constrained by the low level of detail available about the archaeological record, but a tentative explanation might come from pollen sequences in China. These sequences record a Middle Holocene Optimum - a warm-moist event caused by changes in the Earth's orbit - at 82005700 BP (Zhou et al 2001) which may have created favourable conditions for hunter-gatherer groups in mainland Southeast Asia, but the chronological overlap here is imprecise and there is currently little evidence to support a direct link between this climatic event and hunter-gatherer activity in Thailand. Whatever the ultimate cause, it is noteworthy that there are no signs of any major reorganisation of flaked artefact technology during this time.

A small number of flaked pieces with edge-grinding on them have been recovered from Banyan Valley
Cave, in addition to a ground adze and a flaked quadrangular adze (Reynolds 1992), but the exact chronology of these pieces is uncertain and they may have appeared after this mid-Holocene expansion. If analogy with ethnographic tools is reliable, the archaeological appearance of edge-ground pieces may reflect tree-clearing or ground-working for horticultural activities (Anderson 1990). Although much uncertainty surrounds these Middle Holocene data, one possible explanation for the apparent absence of a reorganisation in flaked stone artefact technology at this time is that the change in climatic conditions resulted in an increase in population, which then posed new problems for resource procurement and mobility organisation. The optimum solution to these problems may have been a major reorganisation of subsistence strategies. This solution probably included a shift in the focus of settlement patterns and landscape exploitation, similar to what was described for Tham Lod and Ban Rai above.

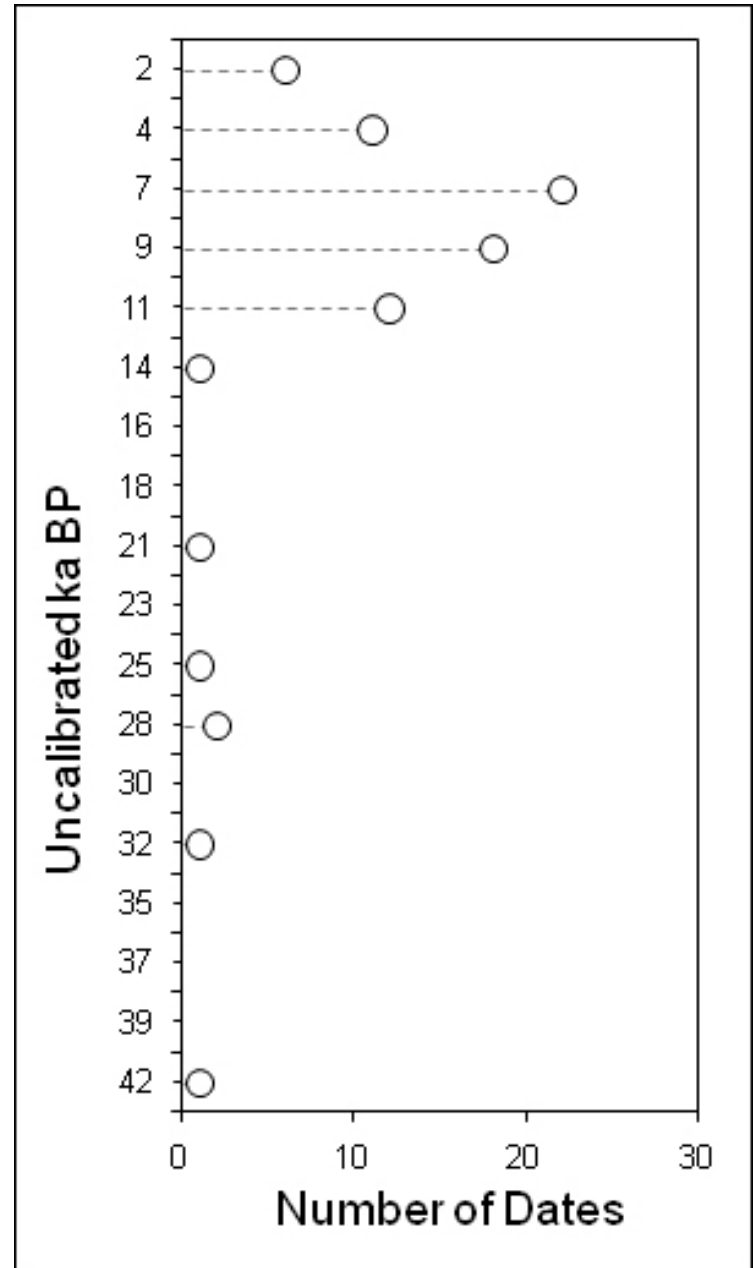

Figure 6 Distribution of radiocarbon dates $(n=76)$ in mainland Southeast Asian archaeological sites dominated by flaked stone artefact assemblages. Data from Reynolds 1990 
Recent work in two regions in mainland Southeast Asia may shed more light on the problem of appearance of edge-ground stone artefacts. One area is the Luang Prabang Province in northern Laos. This area is significant because of its proximity to the Hoa Binh province in northern Vietnam where large numbers of Hoabinhian sites with late Pleistocene and Holocene sequences of flaked stone artefacts have been recorded (White et al 2009). Another significant detail is its proximity to the Sakon Nakon Basin in northeast Thailand where early bronze and ceramic technology has been found in prehistoric village sites (White \& Bouasisengpaseuth 2008). The geographical location of Luang Prabang between these two archaeologically prominent areas is suggestive of its potential, but the most important detail is the unusual abundance of ground-edge stone artefacts in Luang Prabang compared to the two neighbouring areas and indeed all of mainland southeast Asia (Raymaekers 2001; Duff 1970; White \& Bouasisengpaseuth 2008). These details suggest that future work on the appearance of ground-edge stone technology and its role in Holocene transformations of subsistence and settlement would be fruitfully pursued in Luang Prabang.

A second promising region is at similar latitude to Luang Prabang and is also in a major river system, the Salween River. Recent surveys and excavations in this area have recorded a numerically prominent and visually distinctive form of flaked stone artefact that resembles the morphology of ground-edges adzes (Forestier et al 2005; Nakabanlang 2007). These artefacts are occasionally found elsewhere where they are labelled 'adze preforms' (BoerMah 2008) and considered to represent an intermediate step in the manufacture of ground adzes from unmodified nodules of rock. Although ground adzes do not appear to be unusually common in the Salween, as they are in Laos, the relative abundance of these adze preforms in the Salween River area suggests that this area may contain reliable evidence of the appearance of polished adze tools and provide insights about other cultural changes related to adze technology.

\section{Conclusions}

Although flaked stone artefacts are ubiquitous throughout the history of hominin settlement in mainland Southeast Asia, they are currently making their greatest contribution to our understanding of the terminal Pleistocene of mainland Southeast Asian archaeology. The small number of stone artefacts recovered from earlier periods and the uncertainly of the age of the artefacts has limited their contribution to our understanding of hominin behaviour. We can conclude little more than hominins were on the landscape during the Middle Pleistocene. As future work reveals larger and reliably dated stone artefact assemblages then it will be possible to make more credible statements about the role of technology in the first hominin colonisations and technological changes surrounding the local appearance of anatomically modern humans in mainland Southeast Asia.

Recent work on the later Pleistocene and early Holocene in Thailand has suggested that previous conceptual frameworks have lacked the analytical power and resolution to identify the subtle technological and behavioural shifts that appear to characterise the stone artefact archaeology of this period. One notable result from recent work is the difference between the Pleistocene and Holocene periods, with shifts in technological organisation and settlement patterns evident at Tham Lod and Ban Rai. Evidence from the Holocene is suggestive of higher population densities and new technologies such as ground-edge stone artefacts. Two locations with potential to contribute to problems of late Holocene archaeology in mainland Southeast Asia, especially the question of the role of polished adze technology, are Luang Prabang and the Salween River basin.

Although the body of previous work on stone artefacts in mainland Southeast Asia is relatively small, it is clear that one of the main criteria of scientific merit has been adherence to early research traditions (for example of Colani and Movius). Explicit discussion of hypotheses, method and theories has not been prominent in previous work. Here I have advocated a shift to a broad scientific research programme that is based on the use of models as instruments that like evidence to theory, the extraction of hypotheses from models and the confrontation of multiple hypotheses with data as an arbitrator (Hilborn \& Mangel 1997). The formulation of models and hypotheses should encourage more explicit links between data, method and theory, which has been the most serious weakness of the typological approach. For stone artefact studies in mainland Southeast Asia, attribute-based technological analyses of lithic assemblages are likely 
to provide many of these links between method and theory, as they have for archaeologists in other parts of the world.

\section{Acknowledgements}

Much of the research described here was supported by the Highland Archaeological Project in Pangmapha (supported by the Thailand Research Fund and

\section{References}

Abbott, MB, Leonard, RD \& Jones, GT 1996. Explaining the change from biface to flake technology. In Maschner, HDG (ed) Darwinian Archaeologies. New York: Plenum.

Ambrose, SH 2002. Small Things Remembered: Origins of Early Microlithic Industries in SubSaharan Africa. Archeological Papers of the American Anthropological Association, 12:9-29.

Anderson, DD 1990. Lang Rongrien rockshelter: a Pleistocene-early Holocene archaeological site from Krabi, Southwestern Thailand, Philadelphia, University Museum, University of Pennsylvania.

Anderson, DD 1997. Cave archaeology in Southeast Asia. Geoarchaeology, 12:607-638.

Arribas, A \& Palmqvist, P 1999. On the Ecological Connection Between Sabre-tooths and Hominids: Faunal Dispersal Events in the Lower Pleistocene and a Review of the Evidence for the First Human Arrival in Europe. Journal of Archaeological Science, 26:571-585.

Attenbrow, V 2007. What's Changing: Population Size Or Land-use Patterns? The Archaeology of Upper Mangrove Creek, Sydney Basin. Canberra: ANU E Press.

Bacon, A-M, Demeter, F, Rousse, S, Long, VT, Duringer, P, Antoine, P-O, Thuy, NK, Mai, BT, Huong, NTM, Dodo, Y, Matsumura, H, Schuster, $M$ \& Anezaki, T 2006. New palaeontological assemblage, sedimentological and chronological data from the Pleistocene Ma U'Oi cave (northern Vietnam). Palaeogeography, Palaeoclimatology, Palaeoecology, 230:280298.

Bacon, A-M, Demeter, F, Schsuter, M, Long, VT, Thuy, NK, Antoine, P-O, Sen, S, Nga, HH \& Huong, NM 2004. The Pleistocene Ma U'Oi cave, northern Vietnam: palaeontology, sedimentology and palaeoenvironments. Geobios, 37:305-314.

Barker, G, Barton, H, Bird, M, Daly, P, Datan, I, Dykes, A, Farr, L, Gilbertson, D, Harrisson, B \& Hunt, C 2007. The 'human revolution' in lowland tropical Southeast Asia: the antiquity and behavior of anatomically modern humans at Niah Cave (Sarawak, Borneo). Journal of Human Evolution, 52:243-261.

Barr, SM, MacDonald, AS, Haile, NS \& Reynolds, $\mathrm{PH}$ 1976. Paleomagnetism and the age of the Lampang basalt (Northern Thailand) and the age
Silpakorn University) and a PhD scholarship from the Department of Archaeology and Natural History, Research School of Asian Thanks to Rasmi Shoocongdej for her support of my work in Thailand. Thanks to Peter Hiscock, Sue O'Connor and two anonymous reviewers for offering many useful suggestions to earlier versions of this paper.

of the underlying pebble tools. Journal of the Geological Society of Thailand, 2:1-10.

Bekken, D, Schepartz, LA, Miller-Antonio, S, Yamei, $\mathrm{H} \&$ Weiwen, H 2004. Taxonomic Abundance at Panxian Dadong, a Middle Pleistocene Cave in South China. Asian Perspectives, 43:333.

Boer-Mah, T 2008. Reduction and adze form: Ground stone adzes from Ban Non Wat, Northeast Thailand. Bulletin of the Indo-Pacific Prehistory Association, 28:44-51.

Bowdler, S 1994 The Hoabinhian in Australia: A retrospective. Vietnam Social Sciences, 5:87-94.

Bowdler, S 2006. The Hoabinhian: Early Evidence for SE Asian Trade Networks? In Bacus, EA, Glover, IC \& Pigott, VC (eds) Uncovering Southeast Asia's past: Selected papers from the 10th International Conference of the European Association of Southeast Asian Archaeologists. London: The British Museum.

Bowdler, S \& Tan, D 2003. A comparison of stone industries for Southeast Asia and Australia. In Karlstrom, A \& Kallen, A (eds) Fishbones and Glittering Emblems: Southeast Asian Archaeology 2002. Stockholm: Museum of Far Eastern Antiquities.

Bowler, JM, Johnston, H, Olley, JM, Prescott, JR, Roberts, RG, Shawcross, W \& Spooner, NA 2003. New ages for human occupation and climatic change at Lake Mungo, Australia. Nature, 421:837-840.

Brumm, A, Aziz, F, van den Bergh, GD, Morwood, MJ, Moore, MW, Kurniawan, I, Hobbs, DR \& Fullagar, R 2006. Early stone technology on Flores and its implications for Homo floresiensis. Nature, 441:624-628.

Bulbeck, FD 2003. Hunter-gatherer occupation of the Malay Peninsula from the Ice Age to the Iron Age. In Mercader, J (ed) Under the Canopy: The Archaeology of Tropical Rainforests. Piscataway, NJ: Rutgers University Press,.

Chaimanee, Y \& Jaeger, JJ 1994. Pleistocene mammals of Thailand and their use in the reconstruction of the palaeoenvironments of Southeast Asia. SPAFA Journal, 3:4-10.

Choi, K \& Driwantoro, D 2007. Shell tool use by early members of Homo erectus in Sangiran, central Java, Indonesia: cut mark evidence. 
Journal of Archaeological Science, 34:48-58.

Ciochon, R \& Olsen, JW 1991. Palaeoanthropological and archaeological discoveries from Lang Trang Caves: A new middle Pleistocene hominid site from Northern Vietnam. Bulletin of the Indo-Pacific Prehistory Association, 10:59-73.

Ciochon, R, Vu The, L, Larick, R, Gonzalez, L, Grun, R, Vos, JD, Yonge, C, Taylor, L, Yoshida, H \& Reagan, M 1996. Dated Co-Occurrence of Homo erectus and Gigantopithecus from Tham Khuyen Cave, Vietnam. Proceedings of the National Academy of Sciences of the United States of America, 93:3016-3020.

Ciochon, RL \& Olsen, JW 1986. Paleoanthropological and archaeological research in the Socialist Republic of Vietnam. Journal of Human Evolution, 15:623-631.

Colani, M 1927. L'âge de la pierre dans la province de Hoa Binh. Mémoires du Service Géologique de l'Indochine, 13.

Collins, S 2008. Experimental investigations into edge performance and its implications for stone artefact reduction modelling. Journal of Archaeological Science, 35:2164-2170.

David, B \& Lourandos, H 1999. Landscape as mind: Land use, cultural space and change in north Queensland prehistory. Quaternary International, 59:107-123.

Demeter, F, Bacon, A-M, Nguyen, KT, Long, VT, Duringer, $\mathrm{P}$, Rousse, S, Coppens, $\mathrm{Y}$, Matsumara, $H$, Dodo, $Y$, Nguyen, MH \& Tomoko, A 2005. Discovery of a second human molar and cranium fragment in the late Middle to Late Pleistocene cave of Ma U'Oi (Northern Vietnam). Journal of Human Evolution, 48:393-402.

Demeter, F, Bacon, A-M, Thuy, NK \& Long, VT 2004. An Archaic Homo Molar from Northern Vietnam. Current Anthropology, 45:535.

Denham, T 2007. Exploiting diversity: plant exploitation and occupation in the interior of $\mathrm{New}$ Guinea during the Pleistocene. Archaeology in Oceania, 42:41-48.

Detroit, F, Dizon, E, Falgueres, C, Hameau, S, Ronquillo, W \& Semah, F 2004. Upper Pleistocene Homo sapiens from the Tabon cave (Palawan, The Philippines): description and dating of new discoveries. Comptes Rendus Palevol, 3:705-712.

Duff, R 1970. Stone Adzes of Southeast Asia: An Illustrated Typology, Christchurch: Canterbury Museum.

Esposito, M, Chaimanee, Y, Jaeger, J-J \& Reyss, $J-L$ 1998. Datation des concretions carbonatees de la Grotte du Serpent Thailande) par la methode $\mathrm{Th} / \mathrm{U}$. Comptes Rendus de l'Academie des Sciences - Series IIA - Earth and Planetary Science, 326:603-608.

Esposito, M, Reyss, J-L, Chaimanee, Y \& Jaeger, J-J 2002. U-series Dating of Fossil Teeth and
Carbonates from Snake Cave, Thailand. Journal of Archaeological Science, 29:341-349.

Foley, R 1987. Hominid species and stone tool assemblages: how are they related. Antiquity, 61:380-392.

Foley, R. \& Lahr, MM 1997. Mode 3 technologies and the evolution of modern humans. Cambridge Archaeological Journal, 7:3-36.

Foley, R \& Lahr, MM 2003. On stony ground: Lithic technology, human evolution, and the emergence of culture. Evolutionary Anthropology: Issues, News, and Reviews, 12:109-122.

Forestier, H 2000. De quelques chaînes opératoires lithiques en Asie du Sud-Est au pléistocène supérieur final et au début de l'holocène L'Anthropologie, 104:531-548.

Forestier, $\mathrm{H}$, Zeitoun, V, Lenoble, A \& Tiaminkrit, C 2008. Discovery of new old material in the basaltic region of Lampang (Northern Thailand): A techno-fucntional interpretation. In Pautreau, J-P, Coupey, A-S, Zeitoun, V \& Ramblault, E (eds) From Homo erectus to the living traditions: Choice of papers from the 11th International Conference of the European Association of Southeast Asian Archaeologists. Bougon: European Association of Southeast Asian Archaeologists.

Forestier, H, Zeitoun, V, Seveau, A, Driwantor, D \& Winayalai, C 2005. Prospections paléolithicques et perspectives technologiques pour redéfinir le hoabinhien du Nord de la Thaïlande (campagnes 2002-2005). Aséanie, 15:33-60.

Frankel, D 1988. Characterising Change in Prehistoric Sequences: A View from Australia. Archaeology in Oceania, 23:41-48.

Fromaget, J 1940. "La stratigraphie des dépôts préhistoriques de Tam-Hang (chaîne Annamitique septentrionale) et ses difficultés. Proceedings of the Third Far Eastern Prehistory Congress, 1938. Singapore.

Glover, I 1993. Other people's pasts: Western archaeologists and Thai prehistory. Journal of the Siam Society, 81:45-53.

Glover, I 1999. Letting the past serve the present some contemporary uses of archaeology in Vietnam. Antiquity, 73:594-602.

Glover, IC 2001. Archaeology, Nationalism and Politics in Southeast Asia. Hukay: Bulletin of the University of the Philippines Archaeological Studies Program, 3:37-65.

Higham, CFW 1996. A review of archaeology in mainland Southeast Asia. Journal of Archaeological Research, V4:3-49.

Hilborn, R \& Mangel, M 1997. The Ecological Detective: Confronting Models with Data, Princeton: Princeton University Press.

Hiscock, P 2002. Quantifying the Size of Artefact Assemblages. Journal of Archaeological Science, 29:251-258.

Hiscock, P 2008. Archaeology of Ancient Australia, 
New York: Routledge.

Hiscock, P \& O'Conner, S 2006. An Australian perspective on modern behaviour and artefact assemblages. Before Farming [online version] 2006/2 article 4.

Khaokiew, C 2004. Geoarchaeology of Tham Lod rockshelter, Mae Hong Son. MA Thesis. Department of Geology. Bangkok: Chulalongkorn University.

Kuhn, SL 1995. Mousterian Lithic Technology, Princeton: Princeton University Press.

Kuhn, SL 2004. Upper Paleolithic raw material economies at Ucaglzll cave, Turkey. Journal of Anthropological Archaeology, 23:431-448.

Leavesley, MG \& Chappell, J 2004. Buang Merabak: Additional early radiocarbon evidence of the colonisation of the Bismark Archipelago, Papua New Guinea. Antiquity, 78, http://antiquity.ac.uk/ ProjGall/leavesley/index.html.

Mackay, A 2008. A method for estimating edge length from flake dimensions: use and implications for technological change in the southern African MSA. Journal of Archaeological Science, 35:614622.

Marwick, B 2007. Approaches to Stone Artefact Archaeology in Thailand: A Historical Review. Silpakorn University International Journal, 7:4988.

Marwick, B 2008a. Beyond typologies: The reduction thesis and its implications for lithic assemblages in Southeast Asia. Bulletin of the Indo-Pacific Prehistory Association, 28:108-116.

Marwick, B 2008b. Human Behavioural Ecology and Stone Artefacts in Northwest Thailand during the Terminal Pleistocene and Holocene. In Patreau, J-P (ed) Southeast Asian Prehistory: The 11th EURASEAA Conference. Paris: Musée de Bougon.

Marwick, B 2008c. Stone Artefacts and Human Ecology at two Rockshelters in NorthwestThailand. Unpublished PhD. Archaeology and Natural History. Canberra, The Australian National University.

Marwick, B 2008d. What attributes are important for the measurement of assemblage reduction intensity? Results from an experimental stone artefact assemblage with relevance to the Hoabinhian of mainland Southeast Asia. Journal of Archaeological Science, 35:1189-1200.

Matsumura, H \& Pookajorn, S 2005. A morphometric analysis of the Late Pleistocene Human Skeleton from the Moh Khiew Cave in Thailand. HOMO - Journal of Comparative Human Biology, 56:93.

Maxwell, AL \& Liu, KB 2002. Late Quaternary pollen and associated records from the monsoonal areas of continental South and SE Asia. In Kershaw, P, David, B, Tapper, N, Penny, D \& Brown, J (eds) Bridging Wallace's Line: The Environmental and Cultural History and
Dynamics of the SE-Asian-Australian Region, Advances in GeoEcology 34. Reiskirchen: Catena Verlag.

McCall, GS 2007. Behavioral ecological models of lithic technological change during the later Middle Stone Age of South Africa. Journal of Archaeological Science, 34:1738-1751.

Miksic, JN 1995. Evolving archaeological perspectives on Southeast Asia, 1970-95. Journal of Southeast Asian Studies, 26:46-62.

Moore, MW \& Brumm, A 2007. Stone artifacts and hominins in island Southeast Asia: New insights from Flores, eastern Indonesia. Journal of Human Evolution, 52:85-102.

Moore, MW, Sutikna, T, Jatmiko, Morwood, M \& Brumm, $A$ in press. Continuities in stone flaking technology at Liang Bua, Flores, Indonesia. Journal of Human Evolution.

Morwood, MJ, Sullivan, PBO, Aziz, F \& Raza, A 1998. Fission-track ages of stone tools and fossils on the east Indonesian island of Flores. Nature, $392: 173$.

Moser, J 2001. Hoabinhian: Geographie und Chronologie eines steinzeitlichen Technocomplexes in Südostasien, Köln: Lindensoft.

Movius, HL 1948. The Lower Palaeolithic cultures of southern and eastern Asia. Transactions of the American Philosophical Society, 38:329-420.

Nakabanlang, S 2007. From the Pleistocene to the Lanna Period, Chiang Mai, Centre for Northern Archaeology, Chiang Mai University.

O'Connell, JF \& Allen, J 1998. When did humans first arrive in greater Australia and why is it important to know? Evolutionary Anthropology: Issues, News, and Reviews, 6:132-146.

O'Connell, JF \& Allen, J 2004. Dating the colonization of Sahul (Pleistocene Australia-New Guinea): a review of recent research. Journal of Archaeological Science, 31:835-853.

O'Connor, S 2007. New evidence from East Timor contributes to our understanding of earliest modern human colonisation east of the Sunda Shelf. Antiquity, 81:523-535.

O'Connor, S \& Chappell, J 2003. Colonisation and coastal subsistence in Australia and Papua New Guinea: different timing, different modes. In Sand, C (ed) Pacific Archaeology: Assessments and Prospects. Noumea, Departement d'Archeologie, Service des Musses et du Patrimoine.

Olsen, JW \& Ciochon, RL 1990. A review of evidence for postulated Middle Pleistocene occupations in Viet Nam. Journal of Human Evolution, 19:761-788.

Oota, H, Kurosaki, K, Pookajorn, S, Ishida, T. \& UEDA, S. 2001 Genetic study of the Paleolithic and Neolithic Southeast Asians. Human Biology, 73:225-231.

Parry, WJ \& Kelly, RL 1987. Expedient core 
technology and sedentism. In Johnson, JK \& Morrow, CA (eds) The Organization of Core Technology. Boulder: Westview Press.

Pookajorn, S 1984. The Hoabinhian of mainland southeast Asia: new data from the recent Thai excavation in the Ban Kao area. Bangkok: Ban Thai Khadi Research Institute, Thammasat University.

Pookajorn, S 1992. Recent Evidences of a Late Pleistocene to a Middle Holocene Archaeological Site at Moh Khiew Cave, Krabi Province, Thailand. Silpakorn Journal, 35:93-119.

Pope, GG 1985. Taxonomy, dating and palaeoecology of the early Far Eastern Hominids. Modern Quaternary Research in Southeast Asia, 9:65-80.

Pope, GG, Barr, S, MacDonald, A \& Nakabanlang, S 1986. Earliest radiometrically dated artifacts from Southeast Asia. Current Anthropology, 27:275279.

Pope, GG, Frayer, DW, Langchareon, M, Kulasing, $P \quad \& \quad N a k a b a n l a n g$, S 1978. Palaeoanthropological investigations of the Thai-American Expedition in Northern Thailand (1978-1980): An interim report. Asian Perspectives, 11:147-163.

Pramankij, S \& Subhavan, V 2001a. Preliminary Report on the Discovery of Evidence of the oldest Hominids (2 Million to 200,000 years old) in Thailand. Silpa Wattanatham, 23:38-47 (in Thai).

Pramankij, S \& Subhavan, V 2001b. Report on fossils from Hat Pu Dai, Northern Thailand. Unpublished report. Siriraj Medical School, Mahidol University.

Raymaekers, P 2001. Prospection archéologique de la vallée Laotienne du fleuve Mékong, Oxford: Archaeopress.

Reynolds, TEG 1989. Techno-typology in Thailand: A case study of Tham Khao Khi Chan. Bulletin of the Indo-Pacific Prehistory Association, 9:33-43.

Reynolds, TEG 1990. Review of Hoabinhian. In Barnes, G (ed) Hoabinhian, Jomon, Yayoi. Early Korean States: Bibliographic Reviews of Far Eastern Archaeology. Oxford: Oxbow Books.

Reynolds, TEG 1992. Excavations at Banyan Valley Cave, Northern Thailand: A report on the 1972 season. Asian Perspectives, 31:77-97.

Rick, JW 1987. Dates as data: An examination of the Peruvian preceramic radiocarbon record. American Antiquity, 52:55-73.

Roberts, RG, Jones, R \& Smith, MA 1990. Thermoluminescence dating of a 50,000-yearold human occupation site in northern Australia. Nature, 345:153-156.

Roberts, RG, Jones, R, Spooner, NA, Head, MJ, Murray, AS \& Smith, MA 1994. The human colonisation of Australia: optical dates of 53,000 and 60,000 years bracket human arrival at Deaf Adder Gorge, Northern Territory. Quaternary Science Reviews, 13:575-583.
Sasada, M, Ratanasthien, B \& Soponpongpipat, R 1987. New K/Ar ages from the Lampang Basalt, Northern Thailand. Bulletin of the Geological Survey of Japan, 38:13-20.

Schwartz, JH, Vu The, L, Nguyen Lan, C, Le Trung, K \& Tattersall, I 1995. A review of the Pleistocene Hominoid fauna of the Socialist Republic of Vietnam (excluding Hylopatidae), New York: American Museum of Natural History.

Shoocongdej, R 1996. Forager mobility organisation in seasonal tropical environments: A view from Lang Kamnan Cave, western Thailand. PhD Thesis. Ann Arbor, The University of Michigan.

Shoocongdej, R 2000. Forager Mobility Organization in Seasonal Tropical Environments of Western Thailand. World Archaeology, 32: 1440.

Shoocongdej, R 2001. Hoabinhian. In Peregrine, PN \& Ember, M (eds) Encyclopedia of Prehistory. London: Kluwer Academic/Plenum.

Shoocongdej, R 2006. Late Pleistocene activities at the Tham Lod Rockshelter in Highland Pang Mapha, Mae Hong Son Province, Northwestern Thailand. In Bacus, EA, Glover, IC \& Piggott, V (eds) Uncovering Southeast Asia's Past: Selected Papers from the 10th Annual Conference of the European Association of Southeast Asian Archaeologists. Singapore: NUS Press.

Shoocongdej, R \& Staff, ? 2003. author-please translate title - cannot print the characters you supded................................................................ Bangkok: Highland Archaeology Project in Pang Mapha District, Mae Hong Son Province. In Thai.

Shott, MJ \& Weedman, KJ 2007. Measuring reduction in stone tools: an ethnoarchaeological study of Gamo hidescrapers from Ethiopia. Journal of Archaeological Science, 34:10161035.

Surovell, TA \& Brantingham, PJ 2007. A note on the use of temporal frequency distributions in studies of prehistoric demography. Journal of Archaeological Science, 34:1868-1877.

Thorne, A, Grun, R, Mortimer, G, Spooner, NA, Simpson, JJ, McCulloch, M, Taylor, L \& Curnoe, D 1999. Australia's oldest human remains: age of the Lake Mungo 3 skeleton. Journal of Human Evolution, 36:591-612.

Tobias, PV 2002. The Pleistocene Dispersal of Humanity and the Place of Thailand. Siriraj Hospital Gazette, 55:42-54.

Torrence, R. (1989) Re-tooling: towards a behavioral theory of stone tools. In Torrence, R (ed) Time, Energy and Stone Tools. Cambridge: University of Cambridge Press.

Tougard, C 2001. Biogeography and migration routes of large mammal faunas in South-East Asia during the Late Middle Pleistocene: focus on the fossil and extant faunas from Thailand. Palaeogeography, Palaeoclimatology, 
Palaeoecology, 168:337-358.

Tougard, C, Jaeger, JJ, Chaimainee, Y, Suteethorn, V \& Triamwichanon, S 1998. Discovery of Homo $\mathrm{sp}$. tooth associated with a mammalian cave fauna of Late Middle Pleistocene age, northern Thailand. Journal of Human Evolution, 35:4754.

Treerayapiwat, C 2005. Patterns of Habitation and Burial Activity in the Ban Rai Rock Shelter, Northwestern Thailand. Asian Perspectives, 44:231-245.

Van Heekeren, HR \& Knuth, E 1967. Archaeological Excavations in Thailand. Volume 1. Sai Yok. Stone Age Settlements in the Kanchanaburi Province, Copenhagen: Munksgaard.

Van Tan, H 1997. The Hoabinhian and before. Bulletin of the Indo-Pacific Prehistory Association (Chiang Mai Papers, Volume 3), 16:35-41.

Weninger, B, Jöris, O \& Danzeglocke, U 2007.
CalPal-2007. Cologne Radiocarbon Calibration \& Palaeoclimate Research Package. http:// www.calpal.de/, accessed 2007-11-08.

White, JC \& Bouasisengpaseuth, B 2008. Archaeology of the Middle Mekong: introduction to the Luang Prabang province exploratory survey. In Lorrillard, YGM (ed) New research on Laos/Recherches nouvelles sur le Laos. Vientiane \& Paris: Ecole française d'ExtrêmeOrient.

White, JC, Lewis, H, Bouasisengpaseuth, B, Marwick, B \& Arrell, K 2009. Archaeological investigations in northern Laos: New contributions to Southeast Asian prehistory. Antiquity 83, project gallery.

Zhou, W, Head, MJ \& Deng, L 2001. Climate changes in northern China since the late Pleistocene and its response to global change. Quaternary International, 83-85:285-292. 